\title{
“Critical Evaluation, Analysis and Suggestions for Improvement of the Value Chain- A Case Study onZappos.com”
}

\author{
Tarun Kanti Bose ${ }^{1}$ \\ ${ }^{1}$ Assistant Professor, Business Administration Discipline, Khulna University, Khulna- \\ 9208, Bangladesh \\ tarun $84 \mathrm{ku} @ \mathrm{yahoo} . \mathrm{com}$
}

\begin{abstract}
:
This article is all about evaluating the value chain strategies and activities of the Zappos.com and also come-up with solutions and suggestions regarding what the organization should do to improve its operation. Zappos.com was the leading online seller of shoes in the U.S. It has been a real success story for the corporation since it has started to sell shoes online. However, recently the corporation faces few obstacles in the business operation mainly due to the ongoing worldwide financial crisis which mostly hits almost every business organizations in the US. In later times the organization understood the fact that in order to provide even better services to the customers they need to ensure the best possible value chain. The most highlighted challenges Zapposs.com faced in maintaining the value chain was the scheduling of product delivery, inventory management, demand estimation, distribution of product. This study has suggested few suggestions for the company including-own retail stores, up-to-date and efficient software and programming, diversification, a perfect system of tracking and inventory management, sustainable relationship with suppliers, strong and attacking promotion policy and selecting perfect location.
\end{abstract}

\section{Key Words}

Value Chain, Zappos.com, problems areas, suggestions

\section{Introduction:}

Business world is the place of battle of supremacy. In this turbulent and ever changing business environment every business organization is striving towards obtaining that desired supremacy over others (Allnoch, 1997). Gaining supremacy and competitive advantages are even more difficult in this $21^{\mathrm{ST}}$ century as almost every business organization has the ambition and tenacity to do well. That ambition and desire to go ahead triggers business firms to adopt new and new strategies for delivering best possible value to the customers. In order to deliver the best possible value to the customers those business organizations always wants to create such value chain that will enable them to reach the heart of the customers and occupy a permanent and untenable position in their mind (Agrawal and Pak, 2001). Effective value chain management is without any doubt a very proficient business weapons to have in the armoury of every business organization. It ensures virtually everything for providing sound and better customer value and also assists to build long term sustainable relationship with the customers (Godsell and Harrison, 2002).

DOI: 10.5121/ijmvsc. 2012.3304 
International Journal of Managing Value and Supply Chains (IJMVSC) Vol. 3, No. 3, September 2012

\section{The Concept of Value Chain and its Immense Importance:}

The term "Value Chain" was first incorporated by Michael Porter in his book "Competitive Advantages" (Hines, 1993). The concept of value chain widely defined as the composition of some inter related value-adding activities that helps the organization in converting inputs into outputs in an efficient and effective manner and helping to create and sustain competitive advantages (Walters et al., 2000 and Hines and Rich, 1997). In normal cases a value chain consists of five primary activities in the form of: inbound distribution or logistic, manufacturing operations, outbound distribution, marketing and selling and after-sales services. The value chain also has four supporting activities as: purchasing or procurement, research and development, human resources management and corporate infrastructure (Porter, 1985 and Closs et al., 1998). The value chain in essence interprets the activities of the organization and relates it with competitive strengths and weaknesses in the market settings (Anderson and Mittal, 2000 and Ballou et al., 2000).

An efficient and suitable value chain management is always the key for providing best products and services to the market place (Allnoch, 1997 and Walters and Rainbird, 2004). A typical value chain can be done in few steps. Those steps consists of firstly, analyzing the value chain of the company itself, then analyzing the value chain of the customers so that the organization can identify how the product will fit into the value chain of the customers, then analyzing the value chain of the competitors and finally identifying the potential value added for the customers through the company products or services (Corbett and Blackburn, 1999 and Gereffi et al., 2005).

From the above analysis it is obvious that an efficient value chain is always the key for providing best possible products or services to the customers. In the modern business world it is also of more significance. Every organization is trying their best to build the best possible value chain as the resource base is shorter now and market also getting shrinking day by day (Oswald and Micheal, 2009). The business of online retailers is no exception and we get that idea from the case study of Zappos.com.

\section{Evaluation of Value Chain Strategy for Zappos.com:}

Zappos.com was the leading online seller of shoes in the U.S. It has been a real success story for the corporation since it has started to sell shoes online. But the journey of selling shoes online was not a smooth one for the company. When the founder of the organization proposed about selling products online, the concept received stiff criticisms from various groups of the organization. But afterwards it opens new door for the company and as of 2008 its anticipated sells amount is as much as $\$ 1$ billion. That vast amount of profit is really remarkable for the company considering the fact that it only has initiated the operation only 10 years back. However, recently the corporation faces few obstacles in the business operation mainly due to the ongoing worldwide financial crisis which mostly hits almost every business organizations in the US. This article is all about evaluating the value chain strategies and activities of the organization as a .com company and also come-up with solutions and suggestions regarding what the organization should do to improve its operation. Those suggestions and solutions will be provided by giving examples of the global leading and pioneer .com companies (Hoyt and Marks, 2011).

The historical success story and current situation of Zappos.com reveals a quite interesting story to look at. Evaluating the value chain of the organization is really an unprecedented experience and a breathtaking act. 
The concept of selling shoes online was really a wonderful thought considering the fact that it is always difficult for the customers to get the shoes of right size colour and shape by visiting stores to stores. Zappos.com understood the fact that it can make the job of the customers far easier by putting all the information of the product on internet and customers can get their desired product very quickly only by visiting the websites within a short span of time. Their idea of selling shoes online also boosted by the boom of internet during 1999. Selling shoes online enables them to create a successful value chain which is also very much suited with the demand of modern times (Hoyt and Marks, 2011).

When Zappos.com started the operation in 1999, the total shoe market in the U.S was about $\$ 40$ billion and only $5 \%$ of that done through mail order. The company found their opportunity on that fact. They believed that they can satisfy the needs of the their customers in better ways if they incorporate online selling by providing catalogs in the web sites and customers can easily choose their priority and can give order. That system was really worth of taking considering the fact that, in modern times that particular value chain is the more efficient which can fulfil the customers' needs in better ways. In that sense the concept of Zappos.com to sell shoes online was really a praiseworthy and suitable one (Hoyt and Marks, 2011).

Looking at the value chain strategy of Zappos.com portrays the fact that they always looking for building a strong loyal customer base. They believe that only loyal customers can ensure long term sustainable relationship with the company and ultimately can make the company a real profitable one. Alongside building a loyal customer base another major strategy of the company was not to look for immediate profit rather tries to build the corporation and look for sustainable growth. These strategies are the major reasons behind the historical and unprecedented success of the Zappos.com Corporation (Hoyt and Marks, 2011).

Zapposs.com also believed in maintains strong organizational culture for ensuring the best possible value chain for the customers. It always maintains the workplace suitable for working. It also ensured that the working environment will be enjoyable where everyone will just have fun to work there. Ensuring fun at the workplace was a major reason for their high success in the business process. Zappos.com always trusted its employees. The organization believes that if they can satisfy the employees ultimately that will contribute towards making the value chain efficient and penultimately customers will be satisfied and their goal of building loyal customer base will be obtained (Hoyt and Marks, 2011).

Zappos.com established value chain to ensure WOW for the customers. It always strive towards achieving WOW in its every sphere of operation It wanted to give its customers the most wonderful experience while shopping so that the customers can remember the event and that will trigger their future purchase. The company believes that providing customers the best possible services should never be considered as an expense rather it is an investment that can pay back in great way. Best customers service will ensure high performance, high performance will ensure high percentage of customer satisfaction and high percentage of customer satisfaction will ensure loyal customers (Hoyt and Marks, 2011).

In order to achieve WOW in their value chain and customer service the company ensure the fastest website in their armoury. That particular website was faster than any other rival retail firms. Alongside the internet facility for taking orders from the customers the company also utilize telephones services up to the greatest extent. They ensure toll free numbers. That numbers assist the customers profoundly to give their orders without any expenses. Through telephone and internet the company use to provide every possible information to the customer at the quickest possible of time. Those information include products, price, location, delivery times and also many other important aspects. Those activities really helps the organizations to build the most efficient and smooth value chain for serving the customers (Hoyt and Marks, 2011). 
International Journal of Managing Value and Supply Chains (IJMVSC) Vol. 3, No. 3, September 2012

Another significant and important policy in the value chain of Zappos.com was the fit and return policy. That particular policy was a real good one considering the fact that it is unlikely that shoes will fit to each and every customers at the first purchase occasion. In order to make customers feel free from risks and purchasing consequences the company first implemented 60 days and then 365 days fit and return policy. That ensures remarkable value into the value chain of the company. That makes customers really free from thinking a lot. They were purchasing many kinds of shoes online as they can return those anytime if they virtually want to do so. Fit and return policy was definitely a wonderful addition into the value chain of Zapposs.com (Hoyt and Marks, 2011).

It is the most common characteristics of customers that they always want to avail as many information as possible prior to purchase a certain product. It is always the responsibility for the providers to ensure that. The case is of more significance for online or .com companies like Zappos.com. The company was also not behind understanding that particular fact. They always uploaded the pictures of the shoes and also from different angles to give clear idea to the customers regarding product design and variety (Hoyt and Marks, 2011).

Apart from that the company also put detail information and expert's opinion besides the pictures of the shoes and also customers can make their comments regarding the design and price of those shoes. It was really a wonderful idea to have those facilities on the internet as those acts and information provided the customers all kinds of required data prior to make their purchase decision (Hoyt and Marks, 2011).

Zappos.com use to deal with $95 \%$ of orders through online. In Addition the rest of the orders use to take place via a call centre. The call centre was there to provide the customers the best possible experience. They consider the interaction with the customers through the call centre as a branding opportunity and they never fall back in fulfilling the demand of each and every customer through the call centre. Call centre operators also provided with training opportunities so that they can efficiently deal with the customers in various cases like order receiving, order delivery, return products dealing, providing information of all sorts etc (Hoyt and Marks, 2011).

Along with above mentions strategies and activities another major addition in the value chain of Zappos.com was to provide the customers the most rapid delivery and also with no additional charge. Zappos.com always wanted to surprise the customers by beating their expectations. In order to do so they have special contract with renowned company UPS. They use to deliver products even at a faster rate than UPS tends to do in normal cases. If customers place and order in the evening they will receive it in the next day. That is even more exceptional considering the fact that the normal delivery tenure of UPS is four to five days. The company believes that surprising customers in a positive way is certainly a big advantage for the company over the competitors and without any doubt it will give them a huge edge over others. Rapid delivery is definitely a wonderful addition into the value chain of the company and that assists them greatly in building strong positive reputation of Zapposs.com (Hoyt and Marks, 2011).

As an online retailer of shoes it was immensely important for Zappos.com to attract different kinds of brands. Simultaneously it was also important to attract the most popular ones which are frequently purchased by the customers. In order to obtain efficiency in brand attraction and selling as well the company started with 60-70 brands and then they customize it according to the demand and purchase pattern of the customers. It helps the organization immensely to obtain operation efficiency as it ensured cost effectiveness and high levels of customer satisfaction at the same time. Initially highly reputed brands were not that much enthusiastic to come up and sell their shoes through Zaposs.com but later they came due to the fact that customers were increasingly getting interested to purchase through internet. Zapposs.com also provided few 
incentives to the high class brands. They offered vertical websites in which the company use to sell shoes at first level and then other cloths and accessorises (Hoyt and Marks, 2011).

The reputed brand companies understood that the customers which visits the site has every chance to visits the later sites as well, as they are passionate customers. By that they are likely to get advantage of more selling which more likely to happen in the internet than on normal physical stores. The existence of reputed and high class brand in the product catalogue was certainly a huge addition in the portfolio of the organization's value chain (Hoyt and Marks, 2011).

In the value chain the most important part is the operation management. The company exercised following practices in the operation management. They implemented the "Drop-Shipp" model in delivering value to the customers. They forwarded the orders to the various shoe companies and shoe companies use to deliver the goods to the customers. Through that process Zapposs.com used to incur no inventory and fulfilment costs. That made their value chain more cost effective. But this approaches had some problems in the areas of information accuracy. The information available in the internet was only $95 \%$ correct and moreover the company never aware about the fact that when customers are actually received the order from the shoe companies. As a result the company changed in style in 2000 . The company started to keep it own inventory. They also purchased few retail stores for boosting the campaign. Along with this Zapposs.com also maintained the traditional "Drop-Shipp" approaches with few partners. The joint campaign was definitely an innovative inclusion in the value chain of the company. Another significant step of the organization was the contract with UPS. In that contract Zapposs.com allows UPS to manage its inventories. It was a big step that made the company's delivery system more efficient as UPS has lot more capabilities and resources. As a result customers use to receive their products at the quickest possible time (Hoyt and Marks, 2011).

In later times the organization understood the fact that in order to provide even better services to the customers they need to establish their own distribution centre. They established their own distribution centre in Kentucky and they incorporated their self-developed software to receive orders, tracking inventories and also deliver goods to the customers. Their distribution centre was an inexpensive one and it was also very close to the location of UPS. In the both ways it assists the company greatly as it enhanced their self distribution competencies and also improves their delivery capacity (Hoyt and Marks, 2011).

The major noticeable factors of the success of the company existed in the area of changing itself according to the demand of the situation. They always review their every actions and steps and try their best to correct themselves. Zapposs.com use to undertake frequent customer satisfaction survey. After 2003 the company realized the fact that the customers are more satisfied when the company itself deliver the order in compare to the traditional "Drop-Shipp" approach. As a result they finally give-up exercising major portion of the "Drop-Shipp" approach. They started to deliver $75 \%$ of the orders through their own inventory and ordering and delivery systems. That step was a huge one in establishing more efficiency in their value chain and penultimately their efficiency was close to 100\% (Hoyt and Marks, 2011).

An efficient value chain requires an efficient supply chain. Zapposs.com use to undertake several strategies and activities in order ensure a suitable supply chain management practice. Previously Zapposs.com use to follow the traditional approaches of buying shoes. But afterwards they hire number of buyers and assistant buyers and they make their purchasing system a customized one. In that system the engaged buyers use to give more orders for those shoes which sells more and less for those which sells comparatively lesser amount (Hoyt and Marks, 2011). 
In the process of making the supply chain more competent Zapposs.com purchased the website of $6 \mathrm{pm} . \mathrm{com}$. After this acquisition the company use to sell the product of Shepherdsville warehouse through this website. This action was certainly added new dimension and efficiency into the value chain of the organization as it enables them to sell more and provide new information to the customers (Hoyt and Marks, 2011).

As the selling through internet was booming, increasingly different manufacturer was inclined to sell directly to the customers. Zapposs.com understood immense business opportunity there. As a result they incorporated "Powered by Zapposs" program. In that program the organization run the websites of the manufacturers and assist them to sell shoes directly to the customers. Zapposs.com use to put the logo of "Powered by Zapposs" in the website of manufacturers as well as on the Zapposs website. The customers can purchases products from those locations by clicking on the logo. It was a significant inclusion in the value chain considering the fact that it enables the company to sell more and also developing brand equity and also generating good reputation and publicity (Hoyt and Marks, 2011).

The most highlighted challenge Zapposs.com faced in maintaining the value chain was the scheduling of product delivery. They sue to schedule delivery of products of near about 1400 brands. As usual they normally take the service of UPS and the target was to get the product into the track within 4 hours of the order placement of the customers. That created major traffic management difficulties and there was no certainty that the orders will be received or not. They always tried their best to improve the condition but it always remains as a major issue to address and an area of improvement for the company (Hoyt and Marks, 2011).

Zapposs.com also faced challenges in deciding the best possible inventories according to season. They find it hard to make the product available according to the purchase pattern of the customers in different seasons. As the season progress the sells slowdowns. The company use to lower the prices for boosting-up the sales and also for making rooms for upcoming inventories of the next season. It was done manually and there was no integrated system for doing it more efficiently. In spite of that overstocking was resulted and the company has to take actions like automated discounts program. In addition the company also opened several outlets to sell this overstocked shoes at discounted prices. It was good thinking but it shows bit of inefficiency in the value chain management of the company (Hoyt and Marks, 2011).

Zapposs.com always looks for continuous improvement and they understood that they need to improve in the areas of inbound freight and outbound freight as well. Another problem they faced in their value chain and supply chain management was the transportation of partial loaded track. It was highly ineffective from cost point of view and in these areas the company needs to improve immensely (Hoyt and Marks, 2011). Analyzing the companies value chain evaluates the fact that throughout these years the company carried out it value chain quite well and that is the reason behind its sky-high success. In recent times they faced some problems due to the economic crisis and also due to the change of consumer behaviour (Hoyt and Marks, 2011).

Those issues are forcing the company to rethink about its value chain strategies and look for improvement. The case study reveals that they need to improve in ordering, tracking, buying, inventory management, transportation and also about to future expansion in international business. In order to resolve these areas and improve the operation there is no better way than following the footsteps of other global leading .com companies (Hoyt and Marks, 2011).

\section{Suggestions and Analysis of Improvement:}

Zaposs.com is definitely performing well in their business operation. However, there is always scope for improvement specially considering the ongoing financial crisis and ever changing business environment. They have few problem areas. Alongside those problems areas they also 
need to improve in the field of operations they are doing well now. For doing so Zapposs.com can follow following practices that are done by the com companies in order to maintain a smooth value chain.

Zaposs.com faced some problem in ensuring risk free delivery to the customers at the quickest possible time. It is always important for an online retailer to be very efficient in its delivery pattern and mode. In order to enhance its current status and eliminate delivery problems the company can follow the US retail giant Wal-Mart. Not only Wal-Mart has its own retail stores but also it sells online. In order to deliver good at the desired time the company has its own transportation system which is very efficient without any doubt. Through that they not only transport goods from suppliers but also deliver goods to the customers after the customers place their order. It is definitely expensive for Zapposs.com to have such system but if they can finance and adopt such transportation facility it will enhance their competencies immensely (Hines and Samuel, 2006, Jones and Riley, 1985 and Rajib et al., 2002).

Zapposs.com also faced problems of inventory management. As an online retailer it will damage them badly if they cannot solve that problem. Online companies have to adopt efficient software and programming to be up-to-date and also to gain competitive advantages. The information and tracking and ordering system of the company seems to be outdated and they need to invest in new technologies. The giant online company of Us: E-bay always changed and updated their system technologies and software and hardware to make it according to the demand of situation and times. As more people are now using internet and the sales are increasing day by day-the website of $90 \mathrm{~S}$ are certainly not suitable for $21^{\mathrm{ST}}$ century. So, E-Bay always purchased and upgrades its systems competencies. Zapposs.com also needs to do the same practice for gaining more efficiency into its value chain management (Gereffi et al., 2005 and Hewitt, 1994).

Business world is the most uncertain outset of the planet. We can never be sure what will happen tomorrow in our business. Diversification is the key for long term sustainable success as it lessen the risks of failure. That is why world's global pioneer companies including the retail giants make their products or service portfolio a diversified one. So that they can make their value chain efficient and simultaneously can also minimize the risks of total failure. The global online giant Amazaon.com is a prime example of that. They sell different kinds of product of different brands worldwide. It ensures risks minimization for the company and also it makes their value chain sooth. Currently Zapposs.com normally sells shoes and few other relative goods. But in this turbulent business environment they need to adopt different diversified product portfolio, so that they are risk free if the sales of shoes go downward (Balsmeier and Voisin, 1996 and Charles et al., 2002).

Business is always all about customers and it is important for every company to get the inside information of the customers. There are nearly 222 online retail companies in the U.S. Most of them are striving very hard to get competitive advantages. Successful retail companies like Amazon.com-who sells different goods, Best Buy-who sells electronic goods online, American Exchange-who sells books online, CompUSA-who sells computer devices and software, DVDEnpire.com-who sells DVDs online, Gold star Events-who sells tickets for entertainment programs, J.Crew-who sells apparel for women and children online and many other such companies always conduct online consumer surveys. Their goal of conducting such survey is only to ensure their value chain is exactly what the customers are wanting and demanding. It seems like Zapposs.com seldom use to conduct such surveys. But in order to make their value chain the best one and also customer driven they should seriously consider doing of such survey (Corbett and Blackburn, 1999, Hauser and Clausing, 1988 and Kumar et al., 2006). 
International Journal of Managing Value and Supply Chains (IJMVSC) Vol. 3, No. 3, September 2012

Zapposs.com always faced a great difficulty in maintaining perfect inventory according to the demand of season and also during the off-season period. To solve this problem they require adopting a perfect system of tracking and inventory management. They use to reduce price manually so that the overstocking problems can be reduced. But that particular manual system is not appropriate in this modern century. That is why they should develop and operate a new system to ensure smooth ordering and inventory management during different season following the footsteps of global leading .com companies like Tesco, Staple Inc. Home Retail Group, Neckermann Gruppe, of Europe and also retail corporations of the US like The Kroger Company, Costco, Home Depot, Target, Walgreen etc (Ross, 1998 and Yuan-Jye and Yu-Hua, 2007).

Suppliers are also a key ingredient of efficient supply chain and also value chain management. Zapposs.com use to sell the shoes of some reputed brands but they fail to establish long term relationship with the suppliers for sustainable relationship and development for mutual benefit. That is always the key for smooth business operation of a retail company as the success of Retail Company always strongly depends on the efficiency of supplier's management and relationship building. The PPR SA Company who is the retailing giant of Europe obtaining about 2.3 billion Euros of revenue also found to be maintaining strong relationship with the suppliers (Taylor, 2005).

They sale luxuries goods through online and stores and it is very important for them to establish such relationship otherwise they will not be sure about the availability of different items when it is require to be available. The case is also noticeable for other retail company of the US and Europe like Tesco, Staple Inc, Dixon Group, Amazon.com, Best Buy, Super Value, Sears Holding, Safe Way etc (Godsell and Harrison, 2002).

Zapposs.com also found to be suffering from effective distribution policy. In few cases they found to be investing but not at appropriate way. In order to build strong distribution network they can think about building new relationship with global shipping giant companies like Mearsk Sea land and also with leading transportation companies like DHL, TNT Express or FedEx. That will make their distribution campaign smoother and they will be able to deliver goods even faster. The company has good relationship with UPS but that is found to be not enough for fulfilling the demand of customers. Global leading giant companies in this field like Amazon.com, E-BAY, AG Metro, Tesco, Sears all have these kinds of relationship. So, Zapposs.com should definitely follow their footsteps (James 1994 and Sherer, 2005).

Sears holding company of the US which is one of the largest in the country and in the World used to maintain a strong and attacking promotion policy. Their goal is always boosting up the sales by providing different kinds of promotional acts like discounts contests, freebies, networking, social media, celebrity spokespeople and seasonal sneak preview etc. Zaposs.com never uses to practice such things. Those practices will only enhance its value chain and will contribute greatly in obtaining a good position in the mind of the consumers (Zokaei and Simons, 2006).

The world's and UK's retail giant Tesco is famous for its location strategy. It not only sells goods through physical retail stores but also through online as well. It always found to be selecting the most appropriate location for physical outlet and also warehouses to deliver goods for the online orders. Zpposs.com in recent times found to be opening few of its own stores. But, those are definitely not good enough. In order to make more efficient they should consider to benchmark and follow the strategy of Tesco. It will add significant expertise and efficiency in its value chain and operational campaign towards providing the best possible value to the customers (Tesco, 2006). 
International Journal of Managing Value and Supply Chains (IJMVSC) Vol. 3, No. 3, September 2012

Companies of modern world are always looking for expansion. It is the new way of thinking as the domestic market in Europe and the US is shrinking down and opportunities for expansion are getting intensely convergent. In this scenario all the companies are looking for new market opportunities particularly in Asia and Africa including the emerging markets of India, China and Brazil. A huge portion of annual revenue of number one retail company Wal-Mart came from the global sales apart from the domestic sales in the US. The case is also similar for Amazon.com which is now established itself as truly pioneer global giant of retailing on the web. In order to make the operation more successful and risk free Zapposs.com should consider expanding its operation beyond the home country in the US. That will also help them to make value chain more efficient as by going globally they will be able to capture global HR and other resources in their armoury like every multinational organizations do. In that way it will help them to recover from domestic crisis like the financial crisis of 2008 (Zokaei and Simons, 2006).

\section{Conclusion:}

The history and campaign of Zapposs.com into world of online retail business is without any doubt a remarkable one. Selling shoes on the web in modern century is definitely an innovative idea to say the least. By adopting itself as a retailer on the web the company opened a new era of online retailing in internet. Over the years Zappos.com always tried hard to adopt different suitable and diversified strategies for establishing and improving its value chain continuously. The campaign is definitely successful so far without any slimmest of doubt. They hutted badly by the financial crisis in 2008 and need to recover from that. However, if they are ready to change the strategy of the organizational according to the demand of time and also follow the footsteps of global giant companies in its field as well in other fields, there are no reasons why they will not be able to touch the desired destiny. In order to achieve that destiny Zapposs.com always have to be on the edge of its sit and ready to chop and change strategies for maintaining the most appropriate value chain to ensure best possible customer relationship and long term sustainable success for the company (Bowersox et al., 1999 and Zokaei and Simons, 2006).

\section{References:}

1. Agrawal, M.K. and Pak, M.H. (2001), "Getting smart about supply chain management", McKinsey Quarterly, 2, pp. 22-7.

2. Allnoch, A. (1997), "Efficient supply chain practices mean big savings to leading manufacturers", IIE Solutions, 29 (7), pp. 8-9.

3. Anderson, E. W. and V. Mittal (2000), 'Strengthening the satisfaction profit chain'. Journal of Service Research 3(2), pp. 107-120.

4. Ballou, R.H., Gilbert, S.M. and Mukherjee, A. (2000), "New managerial challenges from supply chain opportunities", Industrial Marketing Management, 29 (1), pp. 7-18.

5. Balsmeier, P.W. and Voisin, W.J. (1996), "Supply chain management: a time-based strategy", Industrial Management, 38(5), pp. 24-8.

6. Bowersox, D.J., Closs, D.J. and Stank, T.P. (1999), $21^{\text {st }}$ Century Logistics: Making Supply Chain Integration a Reality, Council of Logistics Management, Oak Brook, IL.

7. Charles H. Fine, R. Vardan, R. Pethick and J. El-Hout, (2000) "Rapid-Repsonse Capability in Value-Chain Design” (2002), MITSloan Management Review, 43(2), pp. 14-23.

8. Closs, D.J., Roath, A.S., Goldsby, T.J., Eckert, J.A. and Swartz, S.M. (1998), “An empirical comparison of anticipatory and response-base supply chain strategies", International Journal of Logistics Management, 9(2), pp. 21-34.

9. Corbett, C.J. and Blackburn, J.D. (1999), "Partnerships to improve supply chains", MIT Sloan Management Review, 40(4), pp. 71-83.

10. Gereffi, J. Humphrey, G and Sturgeon, T (2005), "The Governance of Global Value Chains," Review of International Political Economy, 12(1) pp. 78-104. 
International Journal of Managing Value and Supply Chains (IJMVSC) Vol. 3, No. 3, September 2012

11. Godsell, J. and Harrison, A. (2002), "Customer responsive supply chains: an exploratory view of performance measurement", paper presented at PMA Conference, Boston, MA.

12. Hauser, J.R. and Clausing, D. (1988), "The house of quality", Harvard Business Review, 66 (3), pp. 63-73.

13. Hewitt, F. (1994), "Supply chain redesign”, International Journal of Logistics Management, Vol. 5(2), pp. 1-9.

14. Hines, P. (1993), "Integrated materials management: the value chain redefined", International Journal of Logistics Management, 4(2), pp. 13-22.

15. Hines, P. and Rich, N. (1997), "The seven value stream mapping tools", International Journal of Operations \& Production Management, 17 (1) pp. 17-29.

16. Hines, P. and Samuel, D. (2006), "The development of supply chain relationships: a multi lens approach", working paper, Cardiff Business School, Cardiff.

17. Hoyt, D and Marks, M (2011), Zapposs.com: Developing a Supply chain for delivering WOW, Stanford University

18. James H. D (1994), "Linking Customer Satisfaction to Service Operations and Outcomes," in Service Quality: New Directions in Theory and Practice, Roland T. Rust.

19. Jones, T. and Riley, D.W. (1985), "Using inventory for competitive advantage through supply chain management", International Journal of Physical Distribution \& Materials Management, 15 (5), pp. 16-26.

20. Kumar, V., N. K. Leman, and Parasuraman, A (2006), 'Managing customers for value: An overview and research agenda'. Journal of Service Research 9(2), pp. 87-94.

21. Oswald A. M, R K, Michael, B (2009) "Customer value-chain involvement for co-creating customer delight.” The Journal of Consumer Marketing. 21(7), pp.486-496.

22. Porter, M (1985) Competitive Advantage, Creating and Sustaining Superior Performance, The Free Press, New York.

23. Rajib, P., Tiwari, D. and Srivastava, G. (2002), "Design and development of an integrated supply chain management system in an internet environment", Journal of Services Marketing, 3 (13), pp. 12-19

24. Ross, D.F. (1998), "Competing through supply chain management”, Creating Market-winning Strategies Through Supply Chain Partnership, Kluwar Academic Publishers, Boston, MA.

25. Sherer, S.A. (2005) "From supply-chain management to value network advocacy: implications for e-supply chains," Supply Chain Management, 10, pp. 77 - 89.

26. Taylor, D.H. (2005), "Value chain analysis: an approach to supply chain improvement agri-food chains", International Journal of Physical Distribution \& Logistics Management, 35(10), pp. 74461.

27. Tesco (2006), "Our core purpose", Tesco, available at: www.tescocorporate.com (accessed 2 Janaury, 2011).

28. Waller, M.A., Dabholkar, P.A. and Gentry, J.J. (2000), "Postponement, product customization, and marketoriented supply chain management", Journal of Business Logistics, 21 (2), pp. 133-61.

29. Yuan-Jye, T, Yu-Hua, L (2007). "The Grey Relational Evaluation of the Manufacturing Value Chain.” Journal of American Academy of Business, Cambridge. 7(1), pp. 67-71.

30. Zokaei, K. and Simons, D.W. (2006), "Value chain analysis in improvement of customer focus: a case study of UK red meat industry", International Journal of Logistics Management, 17 (2), pp. 22-35. 